\title{
Comparative Study on Attitudes of Students Studying in Different Types of High Schools towards Physical Education and Sports Lesson
}

\section{Ridvan Dagdemir ${ }^{1}$ Serkan Tevabil Aka ${ }^{2}$}

${ }^{1,2}$ Agr Ibrahim Cecen University, Institute of Social Sciences, Department of Physical Education and Sports, AGRI, Turkey.

Email:mh.salehian@gmail.com

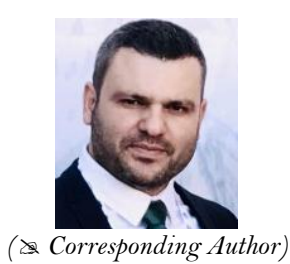

\section{Abstract}

The main purpose of this study was to examine attitudes of students studying in different types of high schools towards physical education and sports lesson in terms of various variables. In this research, comparative survey model has been adopted. Population of the research consisted of students studying in different types of high schools and different grades in Erzurum province in 2016-2017 and its sample group consisted of total 1560 high school students selected by using stratified random sampling. Personal information form and physical education lesson attitude scale developed by Demirhan and Altay were used in order to measure students' attitudes towards physical education and sports lesson. According to the findings, there are significant difference between participant students' gender, grade, school type, mother educational level variables and levels of their attitudes towards physical education lesson according to $\mathrm{p}<, 05$ significance level, but there is no significant difference according to father educational level and residence place variables. As a result, all students studying in different types of high schools in Erzurum have positive attitudes towards physical education and sports lesson. According to high school type, attitudes of Anatolian İmam Hatip High School students towards physical education and sports lesson are at the most positive attitude level when compared to other high school types.

Keywords: Physical education and sports lesson, High school type, Attitude.

Citation | Ridvan Dagdemir; Serkan Tevabil Aka (2019). Comparative Study on Attitudes of Students Studying in Different Types of High Schools towards Physical Education and Sports Lesson. Asian Journal of Education and Training, 5(4): 609-615. History:

Received: 23 September 2019

Revised: 25 October 2019

Accepted: 29 November 2019

Published: 2 January 2020

Licensed: This work is licensed under a Creative Commons

Attribution 3.0 License $($ (c) $)$ Er

Publisher: Asian Online Journal Publishing Group
Acknowledgement: Both authors contributed to the conception and design of the study.

Funding: This study received no specific financial support.

Competing Interests: The authors declare that they have no conflict of interests.

Transparency: The authors confirm that the manuscript is an honest, accurate, and transparent account of the study was reported; that no vital features of the study have been omitted; and that any discrepancies from the study as planned have been explained.

Ethical: This study follows all ethical practices during writing.

\section{Contents}

4. Discussion and Conclusion

References.. 


\section{Contribution of this paper to the literature}

This study contributes to the existing literature by examining attitudes of students studying in different types of high schools towards physical education and sports lesson in terms of various variables.

\section{Introduction}

Physical education covers all of the activities that are done in order to reach the yield strength required by people's physical, cognitive, affective development and genetic capacity appropriate to their age (Bal, 2010). It is very important to implement physical education systematically starting from the first years of the educational period and to ensure development of the programs in terms of the continuity and integrity of education (Ünlü and Aydos, 2007). Physical education is an indispensable part of general education (Aracı, 1998). It is an ideal area where cooperation, appropriate level of competition, personal and social responsibilities are taught (Petithor, 1999). Within the scope of general education, physical education and sports, physical and mental discipline of the individual, obeying the rules, having an understanding of contemporary and modern education, becoming an individual, self-realization, comprehending responsibility and being shaped with these values are compatible with general education and physical education. In developed countries, physical education lesson load has an important place in general education programs. In the understanding of contemporary education, general education is supported by physical education and sports. Again, it is observed that sports education gained in schools in these societies continues in individuals' later lives (İrez, 2012).

It can be thought that one of the most important characteristics which should be provided to individual by physical education and sports activities which are considered as an integral part of educational activities, is development of positive attitudes towards sports (Balyan et al., 2012). According to Ekici et al. (2011) "Attitude is a continuous organization of motivation, excitement, cognition and learning processes of an individual with one aspect of individual's own perception world. Attitude refers to approaching certain objects, concepts and situations or moving away from them while being prepared to showing specific behavior towards them. Attitude is evaluation of an object by an individual as positive or negative. Negative attitudes may manifest themselves by having negative beliefs about objects or ideas, rejecting or disliking them and acting against them. Positive attitudes may also manifest themselves by having positive beliefs about objects or ideas, adopting or liking them." According to Özdemir and Yalın (2000) "it includes behaviors such as continuity, punctuality, desire, vitality and optimism required for individuals to succeed in their duties." According to Akandere et al. (2010) "it is a predisposition of a mental, emotional and behavioral reaction that individuals organize against themselves or any other object, social issue or event around them based on their experience, motivation and knowledge.” According to Hünük (2006) "attitudes are affective factors that shape people's behaviors.

Education is defined as process of culturalization socially and one of the main objectives of education is to reveal hidden strengths and abilities of the students and to move abilities and skills of the students up (Uluıșik, 2016). In general, aim of education is to create a healthy society with an individual and universal culture, to make individuals a harmonious member of the society in which they live, to equip individuals with the knowledge and skills required by the era. Special aims in education are characteristics that are aimed to be gained by students and aims prepared for a specific field (Celikten et al., 2005). There are parallel connection between profession that students want to choose and type of high school they want to go to.

There are many types of high schools in Turkish education system. These types of high schools are known as secondary education institutions that prepare them for both university and profession (http://www.turkpdristanbul.com/lise-turleri-ve-meslek-secimi-rehberi/). Anatolian High School, Anatolian İmam Hatip High School, Multi-Program Anatolian High School, Science High School, Fine Arts High School, Anatolian Girls' High School, Anatolian Girls' İmam Hatip High School, Girls' Vocational and Technical Anatolian High School, Vocational and Technical Anatolian High School, Sports High School, Special Education Vocational High School, Vocational High School of Health and Social Sciences High School are important high school types in Turkey. Physical education and sports lessons are given with similar programs in these high schools. Aim of this study is to measure attitudes of students studying in different types of high schools towards physical education and sports lesson and to examine whether there is a difference in student attitudes towards physical education and sports lesson according to types of high school.

\section{Method}

In the research, comparative survey model which is one of the general survey models and which is frequently used in scientific researches and studies in the field of education has been adopted. Survey models are research approaches aiming at defining the situation in the past or present as it is Koçak (2016). It is frequently used in researches with survey model conducted with Likert type scale and in the field of education (Can, 2014).

Population of the research consists of students studying in different types of high schools and different grades in Erzurum province in 2016-2017 academic year (Anatolian High School, Anatolian İmam Hatip High School, Multi-Program Anatolian High School, Science High School, Fine Arts High School, Anatolian Girls' High School, Anatolian Girls' İmam Hatip High School, Girls' Vocational and Technical Anatolian High School, Vocational and Technical Anatolian High School, Sports High School, Special Education Vocational High School, Vocational High School of Health and Social Sciences High School) and its sample group consists of total 1560 high school students studying in different types of high schools and different grades and selected by using stratified random sampling method which is one of the probability sampling methods.

As data collection tool, personal information form prepared by the researchers has been used in order to determine demographic variables of students participating in the research; "physical education lesson attitude scale" developed by Demirhan and Altay has been use in order to measure students' attitudes towards physical education and sports lesson. 
Personal information form consists of 6 questions aiming to determine demographic characteristics of the students (grade, gender, school type, mother educational level, father educational level, residence place). Physical Education Attitude Scale developed by Demirhan and Altay (2001) consists of 24 items, of which 12 are positive and 12 are negative expressions $(1-5,8,11,13,19,20,22$ and 24). While 120 is the highest score that can be obtained from the scale for which alpha coefficient was found as 0,93, the lowest score is 24. 1-24 score range shows the most negative attitude, 25-48 score range shows negative attitude, 49-72 score range shows neutral attitude, 73-94 score range shows positive attitude, 95-120 score range shows the most positive attitude (Demirhan and Altay, 2001). Data was collected through application of questionnaire and scale by doing face-to-face interviews with the students studying in relevant high school types.

In the analysis of data, frequency distribution has been applied to determe demographic characteristics, Independent Samples $\mathrm{T}$ test to examine relationship between two independent variables and physical education lesson attitude level, One-Way ANOVA analysis tests to examine relationship between more than two variables and physical education lesson attitude level. LSD test has been used to determine which group caused the differences. All these tests have been analyzed in SPSS 21 package program and significance level has been taken as $\mathrm{p}<0,05$.

\section{Findings}

Table-1. Descriptive statistics of students.

\begin{tabular}{l|c}
\hline \multicolumn{2}{l|}{ Physical education lesson attitude level } \\
\hline $\mathrm{N}$ (Total) & 1560 \\
\hline Mean & 89,3417 \\
\hline Median & 89,0000 \\
\hline Mode & 120,00 \\
\hline Std. Deviation & 19,48817 \\
\hline Skewness &,- 302 \\
\hline Std. Error of Skewness &, 062 \\
\hline Kurtosis &,- 512 \\
\hline Std. Error of Kurtosis &, 124 \\
\hline Minimum & 30,00 \\
\hline Maximum & 120,00 \\
\hline
\end{tabular}

As it is found in Table 1, Physical Education Lesson Attitude Level (-,302) values are within $+1,96$ and $-1,96$ standard deviation range from $95 \%$ average. These statistical results show that data shows normal distribution and parametric tests should be applied.

Table-2. Gender distribution of students participating in the research.

\begin{tabular}{c|c|c}
\hline Gender & Number $(\mathbf{N})$ & Percentage (\%) \\
\hline Male & 733 & 47,0 \\
\hline Female & 827 & 53,0 \\
\hline Total & 1560 & 100,0 \\
\hline
\end{tabular}

As it is found in Table $2,733_{(47,0 \%)}$ are male and $827_{(53,0 \%)}$ are female.

Table-3. Distribution of grade in which research participant students.

\begin{tabular}{c|c|c}
\hline Class level & Number $(\mathbf{N})$ & Percentage $\mathbf{( \% )}$ \\
\hline $9^{\text {th }}$ Grade & 390 & 25,0 \\
\hline $10^{\text {th }}$ Grade & 393 & 25,2 \\
\hline $11^{\text {th }}$ Grade & 388 & 24,9 \\
\hline $12^{\text {th }}$ Grade & 389 & 24,9 \\
\hline Total & 1560 & 100,0
\end{tabular}

As it is found in Table $3,390{ }_{(25,0 \%)}$ of students participating in the research are in $9^{\text {th }}$ grade, $393(25,2 \%)$ are in $10^{\text {th }}$ grade, $388_{(24,9 \%)}$ are $11^{\text {th }}$ grade and $389_{(24,9 \%)}$ are in $12^{\text {th }}$ grade.

Table-4. Distribution of school types where research participant students.

\begin{tabular}{l|c|c}
\hline School Type & Number $(\mathbf{N})$ & Percentage (\%) \\
\hline Anatolian High School & 123 & 7,9 \\
\hline Science High School & 121 & 7,8 \\
\hline Vocational High School of Health & 118 & 7,6 \\
\hline Vocational and Technical Anatolian High School & 121 & 7,8 \\
\hline Private High School & 119 & 7,6 \\
\hline Anatolian Imam Hatip High School & 119 & 7,6 \\
\hline Fine Arts High School & 118 & 7,6 \\
\hline Sports High School & 120 & 7,7 \\
\hline Multi-Program Anatolian High School & 120 & 7,7 \\
\hline Anatolian Girls' High School & 122 & 7,8 \\
\hline Social Sciences High School & 120 & 7,7 \\
\hline Anatolian Girls' Imam Hatip High School & 120 & 7,7 \\
\hline Girls' Vocational and Technical Anatolian High School & 119 & 7,6 \\
\hline Total & 1560 & 100,0 \\
\hline
\end{tabular}


As it is found in Table 4, 7,0\% distribution of all school types on average at the rate of 13 different and similar school types.

Table-5. Distribution of mother educational levels of research participant students.

\begin{tabular}{l|c|c}
\hline Mother educational level & Number $(\mathbf{N})$ & Percentage (\%) \\
\hline Primary School & 622 & 39,9 \\
\hline Secondary School & 466 & 29,9 \\
\hline High school & 282 & 18,1 \\
\hline University & 163 & 10,4 \\
\hline Postgraduate (Master's Degree-Doctorate) & 27 & 1,7 \\
\hline Total & 1560 & 100,0 \\
\hline
\end{tabular}

As it is found in Table 5, $622_{(39,9 \%)}$ mothers graduated from primary school and educational level of $27_{(1,7 \%)}$ mothers was postgraduate at the lowest rate.

Table-6. Distribution of father educational levels of research participant students.

\begin{tabular}{l|c|c}
\hline Father educational level & Number $(\mathbf{N})$ & Percentage (\%) \\
\hline Primary School & 298 & 19,1 \\
\hline Secondary School & 386 & 24,7 \\
\hline High school & 501 & 32,1 \\
\hline University & 294 & 18,8 \\
\hline Postgraduate (Master's Degree-Doctorate) & 81 & 5,2 \\
\hline Total & 1560 & 100,0 \\
\hline
\end{tabular}

As it is found in Table 6, $501_{(s, 1 \%)}$ fathers graduated from high school and educational level of $81_{(s, 2 \%)}$ fathers was postgraduate at the lowest rate.

Table-7. Distribution of residence unit of research participant students.

\begin{tabular}{c|c|c}
\hline Residence & Number $(\mathbf{N})$ & Percentage $(\%)$ \\
\hline Village & 234 & 15,0 \\
\hline Town & 18 & 1,2 \\
\hline District & 230 & 14,7 \\
\hline Province & 1078 & 69,1 \\
\hline Total & 1560 & 100,0 \\
\hline
\end{tabular}

As it is found in Table 7, $1078_{(39,1 \%)}$ students lived in province and $18_{(1,9 \%)}$ students lived in town at the lowest rate.

Table-8. Relationship between gender of students participating in the research and their attitudes towards physical education lesson

\begin{tabular}{c|c|c|c|c|c|c}
\hline Gender & N & X & Ss & t & P & Difference \\
\hline Male (1) & 733 & 94,22 & 18,13 & \multirow{2}{*}{9,635} & \multirow{2}{*}{, 000} & \multirow{2}{*}{$1>2$} \\
\hline Female (2) & 827 & 85,01 & 19,63 & & \\
\hline
\end{tabular}

As it is found in Table 8, there is a significant difference. It is observed that total scores obtained by male students from the attitude scale related to physical education lesson are higher than total score of female students.

It has been determined that attitude levels of male students towards physical education lesson are higher than levels of female students. Since total scores of the students in both groups are in the range of 73-94, and that they show positive attitude towards physical education lesson.

Table-9. Relationship between grades of students participating in the research and their attitudes

\begin{tabular}{|c|c|c|c|c|c|c|}
\hline Class level & $\mathbf{N}$ & $\mathbf{X}$ & Ss & $\mathbf{F}$ & $\mathbf{P}$ & Difference \\
\hline $9^{\text {th }}$ Grade (1) & 390 & 92,16 & 18,39 & \multirow{5}{*}{10,101} & \multirow{5}{*}{,OOO } & \multirow{5}{*}{$4<1,2,3$} \\
\hline $10^{\text {th }}$ Grade (2) & 393 & 91,02 & 18,57 & & & \\
\hline $11^{\text {th }}$ Grade (3) & 388 & 89,06 & 19,92 & & & \\
\hline $12^{\text {th }}$ Grade (4) & 389 & 85,08 & 20,32 & & & \\
\hline Total & 1560 & 89,34 & 19,48 & & & \\
\hline
\end{tabular}

As it is found in Table 9, there is a significant difference. It is observed that total scores obtained by students who are in $12^{\text {th }}$ grade from the attitude scale related to physical education lesson are lower than total score of students in $9^{\text {th }}, 10^{\text {th }}$ and $11^{\text {th }}$ grades.

It has been determined attitude levels of students who are in $12^{\text {th }}$ grade are lower than levels of students in $9^{\text {th }}$, $10^{\text {th }}$ and $11^{\text {th }}$ grades. It has been observed that attitude levels of students towards physical education lesson decrease as grade increases. Since total scores of the students studying in different grades are in the range of 73-94, and that they show positive attitude towards physical education lesson. 
Table-10. Relationship between school types of students participating in the research and their attitudes towards physical education lesson

\begin{tabular}{|c|c|c|c|c|c|c|}
\hline School type & $\mathbf{N}$ & $\mathbf{X}$ & Ss & $\mathbf{F}$ & $\mathbf{P}$ & Difference \\
\hline Anatolian High School (1) & 123 & 87,40 & 24,10 & \multirow{14}{*}{3,556} & \multirow{14}{*}{$\begin{array}{l}, 000 \\
, 038\end{array}$} & \multirow{14}{*}{$\begin{array}{c}6>1,4,9,10,12,19 \\
8>9\end{array}$} \\
\hline Science High School (2) & 121 & 89,39 & 20,02 & & & \\
\hline Vocational High School of Health (3) & 118 & 90,64 & 18,73 & & & \\
\hline Vocational and Technical Anatolian High School (4) & 121 & 86,69 & 15,97 & & & \\
\hline Private High School $(5)$ & 119 & 89,76 & 17,88 & & & \\
\hline Anatolian İmam Hatip High School (6) & 119 & 96,60 & 18,51 & & & \\
\hline Fine Arts High School $(7)$ & 118 & 91,88 & 18,19 & & & \\
\hline Sports High School (8) & 120 & 93,82 & 17,58 & & & \\
\hline Multi-Program Anatolian High School (9) & 120 & 85,33 & 16,04 & & & \\
\hline Anatolian Girls' High School (10) & 122 & 87,27 & 20,67 & & & \\
\hline Social Sciences High School (11) & 120 & 90,38 & 22,32 & & & \\
\hline Anatolian Girls’ İmam Hatip High School (12) & 120 & 86,32 & 18,74 & & & \\
\hline Girls' Vocational and Technical Anatolian High School (13) & 119 & 86,11 & 20,23 & & & \\
\hline Total & 1560 & 89,34 & 19,48 & & & \\
\hline
\end{tabular}

As it is found in Table 10, total scores of Anatolian İmam Hatip High School from are higher than Anatolian High School, Vocational and Technical Anatolian High School, Multi-Program Anatolian High School, Anatolian Girls' İmam Hatip High School, Girls' Vocational and Technical Anatolian High School. It is observed that total scores of students of Sports High School are higher than Multi-Program Anatolian High School.

It has been determined that attitude levels of Anatolian İmam Hatip High School towards physical education lesson are higher than Anatolian High School, Vocational and Technical Anatolian High School, Multi-Program Anatolian High School, Anatolian Girls' İmam Hatip High School and Girls' Vocational and Technical Anatolian High School and attitude levels of Sports High School are higher than Multi-Program Anatolian High School. Since total scores of different school types are in the range of 73-94, it is observed that they show positive attitude towards physical education lesson. Since total scores of Anatolian İmam Hatip High School are in the range of 95120, and this school type show the most positive attitude towards physical education lesson.

Table-11. Relationship between educational level of mothers of students participating in the research and their attitudes towards physical education lesson

\begin{tabular}{|c|c|c|c|c|c|c|}
\hline Mother's education & $\mathbf{N}$ & $\mathbf{X}$ & Ss & $\mathbf{F}$ & $\mathbf{P}$ & Difference \\
\hline Primary School (1) & 622 & 90,48 & 20,04 & \multirow{6}{*}{2,542} & \multirow{6}{*}{,028 } & \multirow{6}{*}{$1>4$} \\
\hline Secondary School (2) & 466 & 89,92 & 19,77 & & & \\
\hline High School (3) & 282 & 88,25 & 18,33 & & & \\
\hline University (4) & 163 & 85,47 & 18,77 & & & \\
\hline Postgraduate (Master's Degree Doctorate) (5) & 27 & 87,48 & 14,35 & & & \\
\hline Total & 1560 & 89,34 & 19,48 & & & \\
\hline
\end{tabular}

As it is found in Table 11, there is a significant difference. It is observed that total scores of those mothers' educational level in primary school is higher than mothers' educational university level.

It has been determined that attitude levels of students whose mothers' educational level is primary school towards physical education lesson are higher than levels of students whose mothers' educational level is university. Since total scores of the students whose mothers' educational levels are different are in the range of 73-94, and they show positive attitude towards physical education lesson.

Table-12. Relationship between educational level of fathers of students participating in the research and their attitudes towards physical education lesson.

\begin{tabular}{|c|c|c|c|c|c|c|}
\hline Father's education & $\mathbf{N}$ & $\mathbf{X}$ & Ss & $\mathbf{F}$ & $\mathbf{P}$ & Difference \\
\hline Primary School (1) & 298 & 90,10 & 19,84 & \multirow{6}{*}{, 159} & \multirow{6}{*}{,959 } & \multirow{6}{*}{----- } \\
\hline Secondary School (2) & 386 & 88,93 & 18,91 & & & \\
\hline High School (3) & 501 & 89,25 & 20,07 & & & \\
\hline University (4) & 294 & 89,22 & 19,26 & & & \\
\hline $\begin{array}{ll}\text { Postgraduate } & \text { (Master's } \quad \text { Degree- } \\
\text { Doctorate) }(5) & \end{array}$ & 81 & $89,4 \div 1$ & 18,34 & & & \\
\hline Total & 1560 & 89,34 & 19,48 & & & \\
\hline
\end{tabular}

As it is found in Table 12, there is no significant difference. Since total scores of the students whose fathers' educational levels are different are in the range of 73-94, and they show positive attitude towards physical education lesson.

Table-13.Relationship between residence unit of students participating in the research and their attitudes towards physical education lesson.

\begin{tabular}{l|c|c|c|c|c|c}
\hline Residence & N & X & Ss & F & P & Difference \\
\cline { 1 - 4 } Village & 234 & 90,36 & 17,91 & & & \\
\cline { 1 - 4 } Town & 18 & 85,88 & 19,59 & & & \\
\cline { 1 - 4 } District & 230 & 90,73 & 18,43 & \multirow{2}{*}{, 999} & \multirow{2}{*}{, 392} & - \\
\cline { 1 - 3 } Province & 1078 & 88,87 & 20,02 & & & \\
\hline Total & 1560 & 89,34 & 19,48 & & & \\
\hline
\end{tabular}


As it is found in Table 13, there is no significant difference. Since total scores of the students residing in different residential units are in the range of 73-94, and they show positive attitude towards physical education lesson.

\section{Discussion and Conclusion}

In this research, attitudes of students studying in different types of high schools towards physical education and sports lesson have been examined comparatively in terms of different variables. In the light of findings obtained, results of the study are presented below.

Analysis results of Independent-Samples T test which was conducted in order to determine attitudes and levels of participants for physical education lesson in relation to their gender, were analyzed according to P.0,05 significance level. One-Way Anova LSD test was applied to examine attitudes and levels for physical education lesson related to grade, school type, mother educational level, father educational level, residence unit.

A significant difference has been found between individuals' gender and means of scores obtained from scale of attitudes and levels related to physical education lesson. It has been determined that score means of males $(\mathrm{x}=94,22)$ are higher than score means of females $(\mathrm{x}=85,01)$. Uluışı (2016) determined in their interviews with 1657 students studying in three different secondary schools in 2014-2015 academic year that there was no significant difference in terms of gender and the scores of the participants in $6^{\text {th }}$ grade were higher than the scores of the participants in the $7^{\text {th }}$ and $8^{\text {th }}$ grades, mean scores of participants taking physical education lesson from female physical education teachers were higher than mean scores of participants taking physical education lesson from male physical education teachers and they determined in their study conducted with 212 high school students selected with random sample method that attitudes of students towards physical education lesson did not show significant difference according to gender. Ekici et al. (2011) evaluated physical education attitudes of 387 high school students in Muğla city center. Consequently, significant difference was found according to gender in the items " I do not enjoy attending physical education lesson, I become happy on the day of physical education lesson, my whole day is disarranged on the day of physical education lesson, physical education lesson increases my selfconfidence, I do not recommend my friends to attend physical education lesson, I become happier without a physical education lesson, I think physical education lesson taught me gentlemanship and tolerance, I love physical education lesson, I want physical education lesson to end as soon as possible and I become happier without a physical education lesson".

A significant difference has been found between individuals' grades and means of scores obtained from scale of attitudes and levels related to physical education lesson. It has been determined that means of scores obtained by students who are in $12^{\text {th }}$ grade from the attitude scale related to physical education lesson $(x=85,08)$ are lower than total scores of students in $9^{\text {th }}$ grade $_{(\mathrm{x}=92,16)}, 10^{\text {th }}$ grade $_{(\mathrm{x}=91,02)}$ and $11^{\text {th }}$ grade $_{(\mathrm{x}=89,06)}$. As a result of evaluation of attitudes of 387 high school students towards physical education lesson in Muğla city center by Ekici et al. (2011) significant difference was found according to grades in the items "I want hours of physical education lesson to be increased, I want physical education lesson to be given everyday, my cooperation feeling develops in physical education lesson, I want physical education lesson to end as soon as possible, I love physical education lesson, I hide myself from tasks given related to physical education lesson, my whole day is disarranged on the day of physical education lesson". When Uluışı (2016) examined 150 high school students studying in USO Anatolian High School in Burdur city center according to grade variable in 2015-2016 academic year, it is seen that attitude scores of students in $9^{\text {th }}$ and $10^{\text {th }}$ grades physical education lesson are higher than scores of students in $11^{\text {th }}$ and $12^{\text {th }}$ grades. However, it has been determined that their attitudes towards physical education lesson do not show significant differences according to their grade and gender. As a result of research on relationship between attitudes of 299 students studying in $9^{\text {th }}, 10^{\text {th }}$ and $11^{\text {th }}$ grades in Anatolian High School in Konya towards physical education lesson and their academic motivation by Akandere et al. (2010) it has been stated that attitudes of students towards physical education lesson differentiate according to gender, grade, age groups, status of doing exercise in free time.

A significant difference has been found between individuals' school type and means of scores obtained from scale of attitudes and levels related to physical education lesson. It is observed that total scores obtained by students who are in Anatolian İmam Hatip High $\operatorname{School}_{(\mathrm{x}=96,60)}$ from the attitude scale related to physical education lesson are higher than total score of students in Anatolian High $\operatorname{School}_{(\mathrm{x}=87,40)}$, Vocational and Technical Anatolian $\operatorname{High~School}_{(\mathrm{x}=86,69)}$, Multi-Program Anatolian High $\mathrm{School}_{(\mathrm{x}=85,33)}$, Anatolian Girls' İmam Hatip High $\operatorname{School}_{(\mathrm{x}=86,32)}$, Girls' Vocational and Technical Anatolian High $\operatorname{School}_{(\mathrm{x}=86,11)}$. With these results obtained, it is observed that total scores of students studying in Sports High $\operatorname{School}_{(\mathrm{x}=93,82)}$ are higher scores of students studying in Multi-Program Anatolian $\operatorname{High~School}_{(\mathrm{x}=85,33) \text {. }}$.

A significant difference has been found between individuals' mothers' educational level and means of scores obtained from scale of attitudes and levels related to physical education lesson. It is observed that total scores obtained by students whose mothers' educational level is primary $\operatorname{school}_{(\mathrm{x}=90,48)}$ from the attitude scale related to physical education lesson are higher than total score of students whose mothers' educational level is university $(\mathrm{x}=85,47)$.

No significant difference has been found between individuals' fathers' educational level and means of scores obtained from scale of attitudes and levels related to physical education lesson. In their study conducted on students in elementary school's secondary stage, Koçak and Hurmeric (2006) determined that their attitudes towards physical education did not differentiate according to their families' educational levels after evaluations made accordingly.

It has been concluded that there is no significant difference between residence units of students participating in the research and their attitudes towards physical education lesson.

In general, it is seen that all students studying in different types of high schools in Erzurum have positive attitudes towards physical education and sports lesson. According to high school type, it is seen that attitudes of Anatolian İmam Hatip High School students towards physical education and sports lesson are at the most positive attitude level when compared to other high school types. 
Some suggestions have been made based on the results obtained from the study and other researches;

In this kind of researches, comparisons can be made by applying attitude scale on different age groups and students living in different provinces.

Detection of attitudes developed by students towards physical education lesson can be a guide for educators and program development specialists in the stages of revision of physical education syllabuses, evaluation of the methods used by contributing them.

\section{References}

Akandere, M., N.T. Ozyalvac and S. Duman, 2010. Attitudes of secondary school students towards physical education course and academic success motivation (Example of Konya Anatolian High School). Selcuk University Journal of Social Sciences Institute, 6(2): 36 1372.

Aracı, H., 1998. Physical education in schools. Ankara: Assistant Offset.

Bal, E., 2010. The role of managers and teachers in eliminating the deficiencies encountered in physical education course in primary schools. Master's thesis. Yeditepe Uni The Role of Managers and Teachers in Eliminating the Inadequacies Encountered in Physical Education Course in Primary Schools. Master's Thesis. Yeditepe University Institute of Social Sciences, Istanbul.

Balyan, M., Y.B. Balyan and O. Ve Kiremitçi, 2012. Effects of different sport activities on attitude, social skills and self-efficacy levels of physical education course of elementary school students. Selçuk University Journal of Physical Education and Sports Science, 14(2): 196-201.

Can, A., 2014. Quantitative data analysis in the scientific research process with SPSS. 2nd Edn., Ankara: Pegem Academy Publishing.

Celikten, M., M. Şanal and Y. Yeni, 2005. Teaching profession and features. Journal of the Institute of Social Sciences, $19(2): 207-237$.

Demirhan, G. and F.G. Altay, 2001. Attitude scale of physical education and sport of high school freshman students II. Journal of Sport Sciences, 12(2): 575-584.

Ekici, S., B. Hacicaferoğlu and A. Bayrakdar, 2011. Evaluation of physical education course attitudes of high school students. Journal of Human Sciences, 8(1): 829-839.

Hünük, D., 2006. A comparison of the attitudes of primary school second grade students towards physical education course in central districts of Ankara in terms of class level, student gender, teacher gender and active participation in sports. Master Thesis Hacettepe University Institute of Social Sciences, Ankara.

İrez, S.G., 2012. The effect of physical activity cards application on physical activity levels course contents and teacher behaviors of primary school students in physical education courses. Gazi University Institute of Health Sciences Ph.D.

Koçak, F., 2016. Cycling in Turkey: Reasons and benefits of cycling. Journal of Human Sciences, 13(3): 5760-5771.Available at: https://doi.org/10.14687/jhs.v13i3.4190.

Koçak, S. and I. Hurmeric, 2006. Attitudes toward physical education classes of primary school students in Turkey. Perceptual and Motor Skills, 103(1): 296-300.Available at: https://doi.org/10.2466/pms.103.5.296-300.

Özdemir, S. and H. Yalın, 2000. Introduction to teaching profession. Ankara: Nobel Publication.

Petithor, B., 1999. Physical education methods for classroom teachers. Human Kinetics.

Uluışı, V., 2016. Investigation of secondary school students' attitudes towards physical education course according to class and gender variables. International Journal of Multi-disciplinary Academic Research, 2(3): 45-53.

Ünlü, H. and L. Aydos, 2007. According to teacher views; teaching methods preferred by teachers and students in physical education courses. Ahi Evran University Kırşehir Faculty of Education Journal, 8(2): 71-81. 